\title{
But does it please the Prince?
}

\section{Daniel S. Greenberg}

Science and Technology Advice to the President, Congress, and Judiciary. Edited by William T. Golden. Pergamon: 1988. Pp.523. Hbk £51, \$67; pbk £9.25, \$13.25.

IN RECENT years, the leaders of American science have mainly been snubbed in their devoted attempts to provide presidential science advice as they believe it should be provided. You need us, whether or not you realize it, they have earnestly told a succession of presidents. But presidents tend to see the matter as Machiavelli suggested: "A Prince ... ought always to take counsel, but at such times and seasons only as he himself pleases, and not when it pleases others".

Convinced that his science advisers were politically undisciplined tattlers (as some indeed were in opposing the supersonic transport vehicle and the anti-ballistic missile), Richard Nixon petulantly abolished the White House Office of Science and Technology and its closely affiliated council of wise men, the President's Science Advisory Committee (PSAC). Restored late in the Ford administration at the behest of Congress, the science office held only limited authority under Jimmy Carter. Long afterwards, the committee was revived in skeleton form only. For the first five months of the Reagan administration, the science office existed on a caretaker basis until the appointment of a little-known government physicist, George A. Keyworth II, as director. When he left at the end of 1985, the directorship remained vacant for ten months while the staff dwindled away. Several well-regarded elders of science declined invitations, feeling the job had eroded to a near meaningless state. The eventual appointee, William R. Graham, a right-wing nuclear weapons researcher on the rebound from a misbegotten appointment at the helm of NASA, entered the office with a unique distinction: denunciation by several senators as unqualified for the job. During his brief tenure, the office has sunk so low that the condition of presidential science advice was the subject of an unprecedented congressional hearing in February. Science and government at the White House thus fall short of the noble intimacy prescribed by C.P. Snow and his spiritual brethren.

Does it matter? Obviously not to recent presidents, nor, if campaign statements are the measure, to the current crop of presidential candidates. Nonetheless, the would-be courtiers press on, led by the patron saint of White House science advice, William T. Golden, a man about Wall Street and science and government for nearly 40 years. Asked by President

Truman to recommend a structure for presidential science advice, Golden, in 1950 , proposed an in-house presidential science adviser working in close association with a presidentially appointed parttime committee of distinguished seniors drawn from the scientific enterprise. Presidential interest in this proposition may be inferred from the fact that it wasn't until 1958, the Eisenhower presidency and the political trauma of Sputnik that the Golden prescription was implemented.
Thus began what is nostalgically regarded by many of its participants as the great period of presidential science advice, an era in which Killian from MIT, DuBridge from Caltech and Kistiakowsky from Harvard were at Eisenhower's elbow, while similarly distinguished colleagues from academe routinely commuted to Washington to advise the adviser and even meet the president. The presumably glowing relationship continued into the Kennedy administration, with Wiesner of MIT as the president's science adviser. From arms control to science in the schools, from energy to international research cooperation, nothing was beyond the purview of these high-riding scientist-statesmen, especially the care and feeding of science in the universities, whence virtually all of them came. To outsiders, these people looked very much like an in-house lobby for their own profession. But with heartfelt insistence, many of the survivors of this era claim to have service.

William Golden, contending that "our country has been the poorer" for their performed invaluable, unique public

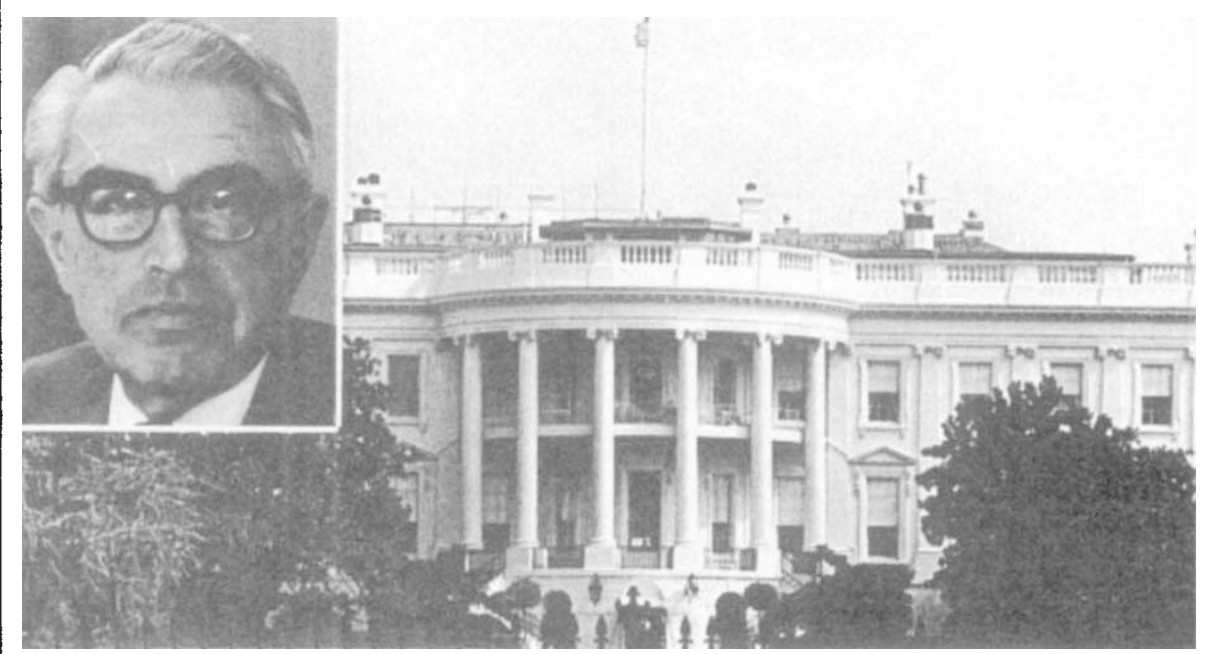

Executive home, with William Golden, "the patron saint of White House science advice".

dismissal from court, yearns for a restoration. In 1980, he commissioned a collection of brief articles, published as Science Advice to the President, arguing the old theme, that you need us, whether or not you know it. Now, returning to pursuit of that goal, he has assembled this unruly mélange of 85 commentaries, mostly focused on science advice for the presidency, with a few devoted to Congress and the judiciary.

About a dozen or so of the essays, mostly by veterans of the presidential advisory service, are firmly rooted in the political realities of life in the White House; they are useful contributions to dealing with the persistently difficult problem of relations between political power and specialized knowledge. Other articles can be characterized as the deliria of the naive and innocent. One writer, for example, urges the president to "sponsor

an annual, heavily publicized prize competition for highly promising, practical, strategic new thrusts in science". And another advises $\mathrm{Mr}$ Reagan to consult Mrs Thatcher if he wishes to emulate "the resurgence of British science, technology, and industrial growth in the 1980s".

Perhaps the sagest contribution is provided by one of the few wise men and original thinkers of American science policy, Alvin M. Weinberg, former director of the Oak Ridge National Laboratory and a member of PSAC during the golden era, 1958-1961. Weinberg usefully deflates the myth of PSAC's omniscience and influence by noting that "On the decision to send a man to the moon, PSAC was ignored... largely, I believe, because most of its members were against the mission". Weinberg correctly observes that presidential science advice was "unorganized and sporadic" when Sputnik inspired Eisenhower to install science advice in the presidency. Today, he points out, "science advice pervades our governmental agencies and departments. Such advice is, above all, institutionalized 
and bureaucratic". And he offers an intriguing proposition: that the Strategic Defense Initiative, widely opposed by scientists as militarily provocative and technologically not feasible, reflects sound political instincts that transcend scientific considerations. Weinberg concludes that "[this administration's] decisions on science matters and on broader policy having scientific components have not been notably worse than in previous administrations where the science advisor had more bureaucratic status. ..".

On the other hand, Frank Press, president of the National Academy of Sciences and science adviser to President Carter, expresses hope that the "younger breed of presidential candidates" will see that they need science advice close at hand "because of the way society is going". He proposes elevating the job in the White House hierarchy, perhaps to cabinet status without portfolio. And he wants to resurrect PSAC. But Press concedes the ultimate political reality: "You can't force it on the president".

The same point is stressed by Solomon Buchsbaum, of AT\&T Bell Laboratories, who has served throughout the Reagan administration as chairman of the White House Science Council, the slimmeddown descendant of PSAC. Noting that "There is much moaning these days about the absence of a 'truly presidential' science advisory mechanism, that is, the absence of a PSAC", Buchsbaum petulantly observes, "the critics expect miracles".

Many who are sceptical about the value of science advice in the White House point out that, in Washington today, science advice, solicited and otherwise, gushes from innumerable organizations, including the National Academy of Sciences, the Congressional Office of Technology Assessment, professional societies, congressional witnesses and so forth. $H$. Guyford Stever, who served as President Ford's science adviser, estimates that the science advising industry has a "collective budget of a good fraction of a billion dollars", and adds, "I do not see that there are important ideas in science and engineering that do not get the attention of the top decision-makers in our country".

The strongest case for the importance of presidential science advice is offered in the volume's only contribution by a recipient of such advice, Gerald Ford, who signed into law the restoration of the White House science office. In justification, he explains: "Presidents don't like surprises". That may be the strongest argument for putting scientific skill directly in the service of the presidency.

Daniel S. Greenberg, 3736 Kanawha Street NW, Washington, DC 20015, USA, is editor and publisher of the newsletter Science \& Government Report.
Assessment of the assessors

Philip Gummett

Evaluating Applied Research: Lessons from Japan. By John Irvine. Frances Pinter/Columbia University Press: 1988. Pp. 103.£27.50, \$45.

THE word 'evaluation' has come a long way from its origins as a term used in the insurance business of the eighteenth century. It now increasingly refers to the latest fashion in science policy, namely, the attempt by governments and other bodies to appraise the quality and benefits of scientific and technological research and development. The search is on for quick, cheap ways of making such appraisals, preferably through the development of sets of 'performance indicators' such as numbers of papers published and subsequent citations, patents awarded or some measure of rate of return on the initial investment. As these approaches spread throughout government, industry and the universities, more and more scientists are becoming aware of them, and of the fact that speed and cheapness in their use can be attained only at the price of sensitivity in their application.

Much of the early work concentrated on evaluation of basic research, mainly using bibliometric techniques. Attention has moved more recently to applied research, defined in this book as "original investigation undertaken in order to acquire new knowledge which is directed towards practical aims or objectives". This definition includes the concept of 'strategic' research, where there are likely to be practical applications but they cannot yet be clearly specified. Obviously, counts of papers and citations will be less valuable for evaluating applied research than for basic, and assessment of the value of the work for eventual practical application will be more important.

The shift in attention towards applied research has been a notable feature of Japanese work on evaluation. This is partly because of the Nakasone government's concern to get better value for public money, but it also owes much to the changing circumstances of Japan's science and technology. The rapid expansion of government-funded research of the $1970 \mathrm{~s}$ has given way to more modest growth. After catching up with the West in many aspects of technology, Japan now feels obliged to pioneer key areas of science and technology. Government laboratories are becoming less concerned with specific applied research in support of industrial ventures, and instead are concentrating more on longer-term strategic research. Finally, there is a growing awareness that the traditional research management procedures, based on the search for consensus, may not be appropriate where relatively radical decisions have to be made, such as closing an institute.

All this has created a need for a better basis for making today's tough decisions over resource allocation, and for ways of minimizing risks as the emphasis shifts from an almost exclusive concern with product and process development towards the less-charted upstream areas of applied research. Accordingly, systematic external reviews have, for the first time, been introduced to Japanese government laboratories and a number of reports have been produced offering guidelines for research evaluation.

\section{IMAGE UNAVAILABLE FOR COPYRIGHT REASONS}

\section{Pointing forward - Japan's Maglev train.}

John Irvine offers an overview of Japanese practice in these respects. Evaluating Applied Research is basically a report prepared for the British government's Department of Trade and Industry. It is therefore written in report style, complete with "Executive" summary (the superfluous adjective is such a ubiquitous feature of report-writing that it too must be seen as a sign of the times). The book emerged from a five-week study, involving interviews at over 20 Japanese organizations. The main substantive chapters are devoted to the evaluation procedures of the Administrative Inspection Bureau (the specialist evaluation arm of the Management and Coordination Agency of the Prime Minister's Office), the Agency of Industrial Science and Technology in the Ministry of International Trade and Industry, and the Science and Technology Agency. It is a pity that the Defence Agency was not included because, even though still a small spender on research and development by Japanese standards, it is growing very fast, particularly in the more upstream areas.

The systematic evaluation of the 140 government laboratories and national 